\title{
TINGGI BADAN ANAK DITINJAU DARI SEGI FAKTOR GENETIK DAN LINGKUNGAN (Studi Antropologi Ragawi Pada Suku Batak Toba)
}

Oleh: Jon Piter Sinaga

Dosen Fakultas Kedokteran Universitas Prima MedanSumatera Utara

\section{ABSTRAK}

Perbedaan tinggi badan dipengaruhi sifatsifat genetik dan perkembangannya dipengaruhi faktor lingkungannya. Penelitian ini menjelaskan interaksi faktor genetik dan lingkungan melalui perbandingan genetis tinggi badan kedua orang tua anak dan analisis lingkungan sosial-ekonomi, anak yang tinggal di daerah pedesaan dan daerah perkotaan.

Populasi penelitian anak dan orang tua yang tinggal di daerah pedesaan meliputi Desa Adiankoting, Desa Banuarea, Desa Horisan yang terletak di Kabupaten Tapanuli Utara dan anak yang tinggal di daerah perkotaan meliputi Kampung Kristen dan Martoba yang terletak di Kotamadya Pematang Siantar, kedua daerah penelitian tersebut di wilayah Provinsi Sumatera Utara. Sifat-sifat genetis tinggi badan ditentukan melalui sifat heritabilitas $\left(h^{2}\right)$ dan polimorfisme genetis (Pg) serta pengaruh lingkungannya ditunjukkan melalui derajat (kekuatan) ekosensitivitas. Sampel penelitian terdiri dari 200 anak yang belajar di Sekolah Dasar (SD) berusia antara usia 8-10 tahun dan masih memiliki kedua orang tua kandung berusia < 45 tahun,

MEDI KORA Vol. IV, No 2, Oktober 2008: 109-129 
100 anak dari pedesaan dan 100 anak dari perkotaan. Dari 100 anak di pedesaan, terdiri dari grup anak laki-laki 47 orang dengan orang tuanya dan 53 anak perempuan dengan orang tuanya, di daerah perkotaan 100 anak, terdiri dari grup anak laki-laki 46 orang dengan orang tuanya dan 54 anak perempuan dengan orang tuanya. Tinggi badan anak dan kedua orang tuanya diukur dengan antropometer dan untuk mengeleminasi perbedaan usia, jenis kelamin dan data antropmetri ditetapkan dengan Z-skor pada tiap-tiap grup. Lingkungan sosial-ekonomi diperoleh melalui teknik wawancara langsung, hasilnya ditetapkan melalui besarnya derajat ekosensitivitas lingkungan dari Status SosialEkonomi (SSE) dari Pelayanan Kesehatan Anak (PKA), Pola Makan Anak (PMA), dan Aktifitas Fisik Anak (AFA). Penelitian berlangsung selama 4 bulan, dilakukan disekolah anak-anak dan dengan mealukan kunjungan ke rumah-rumah orang tua anak. Data antropometri dan kuesioner dianalisis dengan menggunakan uji regressi linear, uji analisis jalur guna mengetahui korelasi dan uji diskriminan dengan tingkat signifikansi $\mathrm{p}$ $<0,05$.

Tinggi badan anak (TB anak) di daerah pedesaan lebih berkorelasi dengan faktor genetis, sedangkan di daerah perkotaan lebih berkorelasi dengan faktor lingkungan terutama pada PKA. Di daerah perkotaan TB anak lebih berhubungan dengan PKA dan PMA. Di daerah pedesaan TB anak lebih dipengaruhi genetis TB ayah, AFA dan PMA. Melalui uji diskriminan diketahui bahwa TB anak yang tinggal di daerah perkotaan lebih tinggi dibangdingkan anak yang tinggal di daerah 
pedesaan. Secara genotip dan interaksi lingkungan dapat disimpulkan bahwa TB anak Suku Batak Toba usia 8-10 tahun, anak laki-laki memiliki genotip heritabilitas $\left(\mathrm{h}^{2}\right)$ TB ibu dan anak perempuan memiliki genotip heritabilitas $\left(\mathrm{h}^{2}\right)$ TB ayah. Dari segi faktor genetis, TB anak lakilaki lebih berkorelasi dengan TB ibu dan TB anak perempuan lebih berkorelasi dengan TB ayah. Dari segi lingkungan TB anak laki-laki di daerah perkotaan lebih berkorelasi dengan faktor SEE dan TB anak perempuan lebih berkorelasi oleh PMA. Di daerah pedesaan TB anak laki-laki lebih berkorelasi dengan PMA dan AFA, bagi anak perempuan lebih berkorelasi dengan PKA.

Kata kunci : genetis, lingkungan, pertumbuhan

Tinggi badan (TB) merupakan produk atau hasil interaksi faktor genetik (gen) dan faktor lingkungan. Menurut hukum keseimbangan Hardy-Weinberg, TB bersifat turun temurun atau diturunkan secara kontinu dari generasi ke generasi berikutnya. Sifat pewarisan genetik TB itu tidak berkelanjutan atau penuh dengan ketidakpastian disebabkan pengaruh dari berbagai perubahan atau keragaman lingkungan. Variasi lingkungan itu ditujukan pada perbedaan SSE berkaitan dengan Pelayanan Kesehatan Anak (PKA), Pola Makan Anak (PMK), serta Aktivitas Fisik Anak (AFA). Status sosial ekonomi (SSE) ditetapkan berdasarkan status

MEDIKORA Vol. IV, No 2, Oktober 2008: 109-129 
pendapatan, pekerjaan, pendidikan dari kedua orang tua anak dalam keluarga.

Pewarisan sifat-sifat tinggi badan disebut faktor genetis merupakan penggambaran interaksi dari variasi pengaturan gen-gen (polygene) dari genetik TB orang tua atau hasil adaptasi genetik yang bersifat permanen, hasil akhir selanjutnya dipengaruhi faktor lingkungannya. Derajat (kekuatan) sifat genetis dari faktor genetik TB kedua orang tua tersebut diekspresikan pada genetis TB anak sebagai fenotip yang dapat diamati melalui heritabilitas $\left(h^{2}\right)$ dan polimorfisme genetis (Pg), selanjutnya derajat ekosensitivitas (De) lingkungannya dapat diketahui melalui Laju Peningkatan Pertumbuhan (LPP) TB anak. Hasil interaksi dari kedua faktor tersebut berdasarkan daerah pedesaan dan perkotaan sampai sekarang belum pernah dijelaskan pada TB anak umur 8-10 tahun.

Frekuensi alel (allelic) yang terdapat pada gen atau pada satu lokus dalam satu kromosom lebih bertanggung jawab terhadap pengaturan gen-gen manusia. Hasil penelitian menunjukkan bahwa setiap alel yang terdapat dalam gamet seseorang memberi tambahan pada tinggi badan. Melalui perbedaan frekuensi alel yang terdapat pada genotip (ayah dan ibu) akan menimbulkan perbedaan TB anak pada umur 
yang sama. Rata-rata TB anak umur 8 tahun dari berbagai bangsa menunjukkan, bahwa TB anak Norwegia telah mendekati $130 \mathrm{~cm}$, Belanda $127 \mathrm{~cm}$, Negro AS $128 \mathrm{~cm}$, Pakistan 113, Papua $111 \mathrm{~cm}$.

Interaksi antara faktor genetik dan lingkungan pada perbedaan TB anak akan ditelusuri pada anak suku Batak Toba umur 8-10 tahun melalui garis keturunan ayah dengan anak kandung ditetapkan atas dasar ikatan satu marga, sehingga pewarisan gen-gen TB ayah dan TB ibu memiliki akurasi yang tinggi. Marga adalah kelompok kekerabatan yang meliputi orang-orang yang percaya bahwa mereka adalah keturunan dari seorang kakek bersama menurut perhitungan garis keturunan ayah (patrilineal). Sistem perkawinan suku Batak Toba sampai sekarang masih dianjurkan kawin sesamanya, atau perkawinan keluarga dekat. Makin renggang hubungan kerabat makin banyak perbedaan pengaturan gen-gennya, karena gen yang terdapat pada kromosom manusia merupakan mata rantai yang mengatur berbagai jenis karakter biologik. Kawin sekerabat (consanguinity) akan bermanfaat untuk mengetahui dan menjelaskan genetis TB manusia dengan memperhatikan faktor heritabilitas $\left(\mathrm{h}^{2}\right)$ dan polimorfisme $(\mathrm{Pg})$,

MEDIKORA Vol. IV, No 2, Oktober 2008: 109-129 


\section{CARA PENELITIAN}

Penelitian ini dilakukan selama 4 bulan, bersifat observasional cross-sectional analytic ditujukan untuk menjelaskan atau eksplanatoris derajat pewarisan genetis tinggi badan orang tua pada anak kandungnya dengan memperhatikan faktor heritabilitas $\left(h^{2}\right)$ dan polimorfisme genetis (Pg) tinggi badan. Data antropometri tinggi badan anak dengan kedua orang tuanya ditetapkan berdasarkan nilai rata-rata $Z$-skor. Populasi penelitian pada suku Batak Toba yang tinggal menetap didaerah pedesaan dan perkotaan, ditetapkan dengan rumus Cochram, 1977. Setelah dilakukan random Multi stage random sampling untuk menetapkan desa/kota dan Simple random sampling untuk menetapkan sampel penelitian maka besar didapat 200 orang anak umur 8-10 tahun. Sampel adalah anak-anak yang tinggal didaerah pedesaan dan perkotaan tinggal menetap bersama kedua orang tuanya umur $<45$ tahun. Anak dibagi dalam 4 grup, 2 grup didaerah pedesaan terdiri dari grup anak laki-laki dan perempuan, 2 grup didaerah perkotaan terdiri dari grup anak laki-laki dan perempuan. Hubungan anak dengan orang tuanya ditetapkan berdasarkan marga dari ayah. 
Variabel penelitian terdiri dari varibel bebas, tinggi badan kedua orang tua (ayah dan ibu) dan lingkungan status sosial ekonomi (SSE) anak meliputi PKA,PMA,AFA. Variable terikat tinggi badan anak dan variabel kendali meliputi suku, umur, desa dan kota. Hasil pengukuran tinggi badan (antropometri) ditetapkan dengan $Z$-skor dan untuk mengetahui derajat lingkungannya dilakukan dengan teknik wawancara langsung setelah kuesioner dilakukan uji validitas dan uji reabilitas. Selnjutnya data antropomeri dan hasil wawancara dianalisis melalui uji statistik :

1. Uji t-test menetapkan perbedaan tinggi badan hasil ratarata Z-skor TB.

2. Uji normalitas menetapkan distribusi normal.

3. Uji homogenitas menetapkan homogenitas varians.

4. Uji regresi linear menetapkan signifikansi derajat faktor genetis dan lingkungan.

5. Analisis jalur menetapkan korelasi derajat genetis TB orang tua dan derajat ekosensinsivitas menetapkan derajat lingkungannya.

MEDIKORA Vol. IV, No 2, Oktober 2008: 109-129 
6. Uji diskriminan menetapkan variabel bebas paling berpengaruh pada TB anak.

\section{HASIL PENELITIAN}

Berdasarkan hasil uji statistik analisis jalur dan uji regresi menunjukkan, bahwa derajat faktor lingkungan sosial ekonomi (De) lebih bermakna atau lebih berpengaruh pada TB anak umur 8-10 tahun dibandingkan dengan derajat faktor genetik. Perbedaan tersebut terjadi pada anak yang tinggal di daerah pedesaan maupun di daerah perkotaan (Tabel 1)

\begin{tabular}{|c|l|r|r|r|}
\hline \multirow{2}{*}{} & Var. bebas & Var. terikat & \multicolumn{2}{|c|}{$\begin{array}{r}\text { Daerah tempat tinggal } \\
\text { anak }\end{array}$} \\
\cline { 3 - 5 } & & $\begin{array}{r}\text { Desa } \\
\text { Kota }\end{array}$ & Desa & Kota \\
\hline $\begin{array}{c}\text { Genetik } \\
\text { TBO }\end{array}$ & Laki-laki & 0.20 & 0.45 & 0.19 \\
\cline { 2 - 5 } & Perempuan & 0.16 & 0.25 & 0.09 \\
\hline \multicolumn{4}{|l}{} \\
\hline $\begin{array}{c}\text { Lingkungan } \\
\text { Sosial } \\
\text { ekonomi }\end{array}$ & Laki-laki & 0.58 & 0.13 & 0.58 \\
\cline { 2 - 5 } & Perempuan & 0.89 & 0.12 & 0.76 \\
\hline
\end{tabular}

Tabel 1.Perbedaan derajat faktor genetik dari genetis TB kedua orang tua dan lingkungannya pada faktor genetik TB anak berdasarkan jenis kelamin dan daerah tempat tinggal anak. 
Interaksi faktor genetik TB kedua orang tua dan lingkungan berdasarkan sosial ekonomi daerah pedesaan dan perkotaan menjelaskan, bahwa:

1. Daerah pedesaan dan perkotaan, menunjukkan: derajat ekosensitivitas (De) lingkungan sosial ekonomi daerah pedesaan dan perkotaan lebih berpengaruh pada TB anak umur 8-10 tahun dibandingkan dengan derajat faktor genetik kedua orang tua anak, baik pada anak laki-laki maupun pada anak perempuan. Dari segi genetik, derajat faktor TB kedua orang tua lebih berpengaruh pada TB anak laki-laki, dan De lebih berpengaruh pada TB anak perempuan.

2. Daerah pedesaan menunjukkan, menunjukkan: derajat faktor genetik TB kedua orang tua di daerah pedesaan lebih berpengaruh pada TB anak umur 8-10 tahun dibandingkan dengan derajat ekosensitivitas (De) lingkungan sosial ekonomi daerah pedesaan. Dari segi genetik, derajat faktor genetik TB kedua orang tua lebih berpengaruh pada TB anak laki-laki.

3. Daerah perkotaan menujukkan, bahwa: derajat ekosensitivitas (De) lingkungan sosial ekonomi perkotaan lebih berpengaruh pada TB anak umur 8-10 tahun dibandingkan dengan derajat faktor genetik kedua orang

MEDI KORA Vol. IV, No 2, Oktober 2008: 109-129 
tua anak, baik pada anak laki-laki maupun pada anak perempuan. Dari segi genetik, derajat faktor TB kedua orang tua lebih berpengaruh pada TB anak laki-laki, dan De lebih berpengaruh pada TB anak perempuan.

4. Derajat faktor genetik lebih berpengaruh di daerah pedesaan dan derajat ekosensitivitas lingkungan sosial ekonomi di daerah pedesaan.

\begin{tabular}{|c|c|c|r|l|}
\hline \multirow{2}{*}{ Var. bebas } & Var. & \multicolumn{3}{|c|}{ Daerah tempat tinggal anak } \\
\cline { 3 - 5 } & terikat & $\begin{array}{c}\text { Desa } \\
\text { Kota }\end{array}$ & Desa & Kota \\
\hline $\begin{array}{c}\text { Genetik } \\
\text { TB ayah }\end{array}$ & Laki-laki & 0.18 & 0.45 & 0.14 \\
\cline { 2 - 5 } & Perempuan & 0.18 & 0.10 & 0.16 \\
\hline $\begin{array}{c}\text { Lingkungan } \\
\text { sosial } \\
\text { ekonomi }\end{array}$ & Laki-laki & 0.59 & 0.53 & 0.51 \\
\cline { 2 - 5 } & Perempuan & 0.74 & 0.77 & 0.76 \\
\hline
\end{tabular}

Tabel 2. Perbedaan derajat faktor genetik dari genetis TB ayah dan lingkungan pada TB anak berdasarkan jenis kelamin dan daerah tempat tinggal anak.

Berdasarkan derajat faktor genetik TB ayah menjelaskan, bahwa: derajat ekosensitivitas (De) lingkungan sosial ekonomi lebih berpengaruh terhadap genetik TB anak laki-laki maupun genetik TB anak perempuan. Dari segi genetik, derajat faktor genetik TB ayah lebih berpengaruh terhadap faktor genetik TB anak laki-laki di daerah pedesaan, akan tetapi di daerah perkotaan lebih berpengaruh pada genetik TB 
anak perempuan. Sedangkan di daerah pedesaan dan perkotaan memiliki pengaruh yang sama. Dari segi derajat ekosensitivitas lingkungan sosial ekonomi lebih berpengaruh pada TB anak perempuan.

\begin{tabular}{|c|c|c|c|c|}
\hline \multirow[t]{2}{*}{ Var. bebas } & \multirow{2}{*}{$\begin{array}{l}\text { Var. } \\
\text { terikat }\end{array}$} & \multicolumn{3}{|c|}{ Daerah tempat tinggal anak } \\
\hline & & Desa Kota & Desa & Kota \\
\hline Genetik & Laki-laki & 0.15 & 0.16 & 0.17 \\
\hline TB ibu & Perempuan & 0.10 & 0.07 & 0.05 \\
\hline Lingkungan & Laki-laki & 0.53 & 0.64 & 0.84 \\
\hline $\begin{array}{c}\text { sosial } \\
\text { ekonomi }\end{array}$ & Perempuan & 0.77 & 0.19 & 0.87 \\
\hline
\end{tabular}

Tabel 3.Perbedaan derajat faktor genetik dari genetis TB ibu dan lingkungan pada TB anak berdasarkan jenis kelamin dan daerah tempat tinggal anak.

Berdasarkan faktor genetik TB ibu menjelaskan bahwa, derajat ekosensitivitas (De) lingkungan sosial ekonomi lebih berpengaruh dibandingkan faktor genetik TB ibu. Dari segi genetik, faktor genetik ibu lebih berpengaruh pada TB anak laki-laki. Dari segi lingkungan, TB anak laki-laki di daerah lebih dipengaruhi faktor lingkunga sosial ekonomi, sedangkan di daerah perkotaan lebih berpengaruh pada TB anak perempuan. Derajat ekosensitivitas (De) lingkungan sosial 
ekonomi yang lebih berpengaruh pada TB anak dibandingkan derajat faktor genetik kedua orang tua.

\begin{tabular}{|c|c|c|c|c|}
\hline \multirow[t]{2}{*}{ Var. bebas } & \multirow[t]{2}{*}{ Var. terikat } & \multicolumn{3}{|c|}{ Daerah tempat tinggal anak } \\
\hline & & Desa Kota & Desa & Kota \\
\hline \multirow[t]{2}{*}{ Genetik TBO } & Laki-laki & 0.20 & 0.44 & 0.19 \\
\hline & Perempuan & 0.16 & 0.25 & 0.09 \\
\hline \multirow{2}{*}{$\begin{array}{r}\text { Lingkungan } \\
\text { SSE }\end{array}$} & Laki-laki & 0.39 & 0.33 & 0.22 \\
\hline & Perempuan & 0.20 & -0.02 & 0.16 \\
\hline \multirow{2}{*}{$\begin{array}{l}\text { Genetik } \\
\text { TB ayah }\end{array}$} & Laki-laki & 0.18 & 0.43 & 0.14 \\
\hline & Perempuan & 0.18 & 0.19 & 0.18 \\
\hline \multirow{2}{*}{$\begin{array}{c}\text { Lingkungan } \\
\text { SSE }\end{array}$} & Laki-laki & 0.48 & 0.27 & 0.17 \\
\hline & Perempuan & 0.21 & -0.00 & 0.16 \\
\hline \multirow{2}{*}{$\begin{array}{l}\text { Genetik } \\
\text { TB ibu }\end{array}$} & Laki-laki & 0.15 & 0.16 & 0.17 \\
\hline & Perempuan & 0.10 & 0.07 & 0.05 \\
\hline \multirow{2}{*}{$\begin{array}{c}\text { Lingkungan } \\
\text { SSE }\end{array}$} & Laki-laki & 0.45 & 0.28 & 0.34 \\
\hline & Perempuan & 0.23 & 0.06 & 0.16 \\
\hline
\end{tabular}

Tabel 4.Derajat faktor genetik dari genetis TBO dan lingkungan SSE pada TB anak berdasarkan jenis kelamin dan daerah tempat tinggal anak.

Hipotesis 1 menyatakan bahwa TB anak di daerah pedesaan dan daerah perkotaan dipengaruhi faktor genetik 
dan lingkungan SSE terbukti dan dapat diterima. Dari segi TBO, derajat lingkungan sosial ekonomi dan derajat faktor genetik TB kedua orang tua lebih berpengaruh pada TB anak laki-laki baik di daerah pedesaan maupun di daerah perkotaan. Dari segi genetik TB ayah, lebih berpengaruh pada TB anak laki-laki di daerah perkotaan dan pada TB anak perempuan di daerah pedesaan. Dari segi genetik Tb ibu, lebih berpengaruh pada TB anak laki-laki baik di daerah pedeasan maupun di daerah perkotaan.

Hipotesis 2 yang menyatakan bahwa TB anak di daerah pedesaan lebih dipengaruhi faktor genetik kedua orang tua dibandingkan faktor lingkungan SSE terbukti dan dapat terima.

Hipotesis 3 yang menyatakan bahwa TB anak di daerah perkotaan lebih dipengaruhi derajat faktor lingkungan SSE dibandingkan derajat faktor genetik kedua orang tua terbukti dan dapat diterima. Selanjutnya, akan dijelaskan persentase pengaruh antara interaksi faktor genetik TB kedua orang tua dengan lingkungan sosial ekonomi anak umur 8-10 tahun suku Batak Toba, dan persentase itu dilakukan berdasarkan koefisen variansi (CV) yang mempengaruhi perbedaan TB anak. Berdasarkan interaksi faktor genetik dan lingkungan

MEDIKORA Vol. IV, No 2, Oktober 2008: 109-129 
sosial ekonomi daerah pedesaan dan perkotaan ditemukan heritabilitas $\left(\mathrm{h}^{2}\right)$ tinggi badan anak

\begin{tabular}{|c|c|c|c|c|}
\hline \multirow[t]{2}{*}{ Jenis kelamin } & \multicolumn{4}{|c|}{ Persentase $h^{2}$ ayah } \\
\hline & $\mathrm{h}^{2}$ & $\mathrm{De}$ & $\mathrm{CV}$ & Ket. \\
\hline Laki-laki & 0.15 & 0.69 & 0.84 & \multirow{2}{*}{$\begin{array}{l}\mathrm{h}^{2} \text { anak } \\
\text { perempuan } \\
\text { lebih } \\
\text { berhubunga } \\
\text { n dengan } \\
\text { genotip TB } \\
\text { ayah }\end{array}$} \\
\hline Perempuan & 0.26 & 0.71 & 0.97 & \\
\hline \multirow[t]{2}{*}{ Jenis kelamin } & \multicolumn{4}{|c|}{ Persentase $h^{2}$ ibu } \\
\hline & $\mathrm{h}^{2}$ & $\mathrm{De}$ & $\mathrm{CV}$ & Ket. \\
\hline Laki-laki & 0.20 & 0.71 & 0.91 & \multirow[b]{2}{*}{$\begin{array}{l}\mathrm{h}^{2} \text { anak } \\
\text { laki-laki } \\
\text { lebih } \\
\text { berhubunga } \\
\mathrm{n} \text { dengan } \\
\text { genotip TB } \\
\text { ibu }\end{array}$} \\
\hline Perempuan & 0.17 & 0.76 & 0.76 & \\
\hline \multirow{2}{*}{$\begin{array}{l}\text { Persentase } \\
\text { genotip TB } \\
\text { ayah \& ibu } \\
\text { pada } h^{2} \text { TB } \\
\text { anak }\end{array}$} & \multicolumn{4}{|c|}{ Persentase $h^{2}$ ayah $\&$ ibu } \\
\hline & $\mathrm{h}^{2}$ & $\mathrm{De}$ & $\mathrm{CV}$ & Ket. \\
\hline $\begin{array}{l}\text { Genotipe TB } \\
\text { ayah }\end{array}$ & 0.21 & 0.57 & 0.78 & $\begin{array}{l}\mathrm{h}^{2} \text { anak } \\
\text { lebih }\end{array}$ \\
\hline
\end{tabular}




\begin{tabular}{|c|l|l|l|l|}
\hline $\begin{array}{c}\text { Genotipe } \\
\text { TB ibu }\end{array}$ & 0.18 & 0.58 & 0.76 & $\begin{array}{l}\text { berhubunga } \\
\text { n dengan } \mathrm{h}^{2} \\
\text { genotip TB } \\
\text { ayah }\end{array}$ \\
\hline
\end{tabular}

Tabel 5. Persentase heritabilitas $\left(\mathbf{h}^{2}\right)$ faktor genetik TB anak umur 8-10 tahun suku Batak Toba berdasarkan daerah pedesaan dan daerah perkotaan.

Derajat heritabilitas TB ayah lebih berhubungan pada anak perempuan dan heretabilitas ibu lebih berhubungan dengan anak laki-laki. Akan tetapi, tinggi badan anak tanpa membedakan jenis kelamin lebih berhubungan dengan heritabilitas TB ayah. Demikian juga derajat polimorfisme genetis (Pg) faktor genetik TB anak yang di dapat dari faktor genetik kedua orang tua dan lingkungannya menunjukkan karakter yang sama dengan heritabilitas kedu orang tua anak.

\begin{tabular}{|c|c|c|c|c|}
\hline \multirow[t]{2}{*}{ Jenis kelamin } & \multicolumn{4}{|c|}{ Persentase Pg ayah } \\
\hline & $\mathrm{Pg}$ & $\mathrm{De}$ & $\mathrm{CV}$ & Ket. \\
\hline Laki-laki & 0.26 & 0.61 & 0.87 & \multirow[b]{2}{*}{$\begin{array}{l}\text { Pg TB anak } \\
\text { perempuan } \\
\text { lebih } \\
\text { berhubungan } \\
\text { dengan } \\
\text { genotip TB } \\
\text { ayah }\end{array}$} \\
\hline Perempuan & 0.32 & 0.53 & 0.85 & \\
\hline \multirow[t]{2}{*}{ Jenis kelamin } & \multicolumn{4}{|c|}{ Persentase Pg ibu } \\
\hline & $\mathrm{Pg}$ & $\mathrm{De}$ & $\mathrm{CV}$ & Ket. \\
\hline
\end{tabular}

MEDIKORA Vol. IV, No 2, Oktober 2008: 109-129 


\begin{tabular}{|c|c|c|c|c|}
\hline Laki-laki & 0.29 & 0.60 & 0.89 & \multirow{2}{*}{$\begin{array}{l}\text { Pg TB anak } \\
\text { laki-laki lebih } \\
\text { berhubungan } \\
\text { dengan } \\
\text { genotip TB } \\
\text { ibu }\end{array}$} \\
\hline Perempuan & 0.25 & 0.57 & 0.82 & \\
\hline \multirow{2}{*}{$\begin{array}{l}\text { Persentase } \\
\text { genotip TB } \\
\text { ayah \& ibu } \\
\text { pada Pg TB } \\
\text { anak }\end{array}$} & \multicolumn{4}{|c|}{ Persentase Pg ayah dan ibu } \\
\hline & $\mathrm{Pg}$ & $\mathrm{De}$ & $\mathrm{CV}$ & Ket. \\
\hline $\begin{array}{c}\text { Genotip TB Pg } \\
\text { ayah }\end{array}$ & 0.29 & 0.57 & 0.86 & \multirow{2}{*}{$\begin{array}{l}\text { Pg TB anak } \\
\text { lebih } \\
\text { berhubungan } \\
\text { dengan } \\
\text { genotip TB } \\
\text { ayah }\end{array}$} \\
\hline $\begin{array}{c}\text { Genotip TB Pg } \\
\text { ibu }\end{array}$ & 0.27 & 0.58 & 0.85 & \\
\hline
\end{tabular}

Tabel 6. Persentase polimorfisme genetis (Pg) TB anak umur 8-10 tahun suku Batak Toba berdasarkan daerah pedesaan dan daerah perkotaan.

\section{PEMBAHASAN}

1. Derajat ekosensitivitas (De) dari PMA yang kurang mendukung lingkungan anak menghambat akselerasio pertumbuhan pada perkembangan TB anak menyebabkan faktor genetis TB orang tua lebih berpengaruh di daerah pedesaan.

2. Derajat ekosensitivitas (De) dari AFA yang kurang mendukung lingkungan anak menghambat akselerasi 
pertumbuhan pada perkembangan TB anak menyebabkan lingkungan lebih berpengaruh di daerah perkotaan.

3. Derajat ekosensitivitas (De) yang paling berpengaruh pada pertumbuhan pada perkembangan TB anak didaerah diperkotaan adalah PMA dan AFA di daerah pedesaan.

4. Secara umum derajat ekosensitivitas (De) lingkungan sosial ekonomi lebih berpengaruh pada TB anak anak lakilaki umur 8-10 tahun baik di daerah perkotaan maupun daerah pedesaan.

5. Tinggi badan anak tanpa membedakan jenis kelamin pada anak suku Batak Toba umur 8-10 tahun dipengaruhi faktor heritabilitas $\left(\mathrm{h}^{2}\right)$ dan polimorfisme genetis (Pg) TB ayah.

6. Derajat ekosensitivitas (De) dan koefisien variansi (CV) lebih berpengaruh pada anak suku Batak Toba umur 8-10 tahun dibandingkan faktor heritabilitas $\left(h^{2}\right)$ TB ayah maupun faktor heritabilitas $\left(\mathrm{h}^{2}\right)$ TB ibu.

7. Koefisien variansi (CV) lebih berpengaruh pada TB anak laki-laki dibandingkan TB anak perempuan.

8. Faktor genetik lebih berhubungan dengan TB anak di daerah pedesaan dipengaruhi sistem perkawinan kedua orang tua dengan ciri masyarakat homogen (inbreed population). dan faktor lingkungan menutupi faktor genetik

MEDIKORA Vol. IV, No 2, Oktober 2008: 109-129 
di daerah perkotaan dipengaruhi sistem perkawinan orang tua dengan ciri masyarakat heterogen (outbreed population).

9. Secara umum PKA yang tidak berpengaruh menyebabkan tidak terpeliharanyan akselerasi pertumbuhan pada perkembangan TB anak secara berkelanjutan

\section{KESIMPULAN}

1. Tinggi badan anak di daerah pedesaan lebih dipengaruhi aktivitas fisik anak (AFA) dan faktor genetik (heritabilitas) TB.ayah

2. Tinggi badan anak di daerah perkotaan lebih dipengaruhi pola makan anak (PMA).

3. Tinggi badan anak tanpa membedakan daerah tempat tinggal adalah faktor genetik ibu lebih pada anak laki-laki dan faktor genetik ayah lebih berpengaruh pada perempuan

4. Tinggi badan anak tanpa membedakan jenis kelamin anak lebih dipengaruhi faktor genetik TB.ayah

5. Derajat ekosensitivitas (De) sosial ekonomi lebih berpengaruh dibandingkan pewarisan konstitusi herediter atau faktor genetik TB kedua orang tua anak 
6. Derajat faktor lingkungan SSE di daerah perkotaan lebih berpengaruh pada TB anak dibandingkan derajat faktor genetik TB kedua orang tua, hal itu mendorong faktor genetik kedua orang tua lebih berpengaruh di daerah pedesaan

7. Hubungan derajat faktor genetik atau heritabilitas $\left(\mathrm{h}^{2}\right)$ TB orang tua pada TB anak dapat menjelaskan pewarisan polimorfisme genetis $(\mathrm{Pg})$.

8.

\section{DAFTAR PUSTAKA}

Atmarita, 1996. Kajian pertumbuhan fisik anak Indonesia berdasarkan SUSENAS 1989, SUSENAS 1992 dan TBAS 1994. Direktorat bina gizi masyarakat. Depertemen kesehatan. 17(1/2): 30-50.

Babbie E, 1986. The practice of sosial research. Research design and Advanced analyses. Fourth edition, Wadsworth Publishing Co, Belmont, California, pp 70 $177,427-445$.

Bogin BA and MacVean RB, 1983. Growth in height and weight of urban Guatemalan primery school children of low and high sosioeconomic class. Human Biology, 50 (4): $477-487$.

MEDIKORA Vol. IV, No 2, Oktober 2008: 109-129 
,BPS Kotamadya Pematang Siantar Dalam Angka Tahun 1997. Badan Pusat Statistik BPS Kotamadya Pematang Siantar, hlm 1-7.

Cochram WG, 1977. Stratified random sampling. Sampling Technical. Third edition. Published simultaneeously in Canada. New York, pp 89149

Evans SA, Kohil HS, 1997. Sosioecnomic status and prevention of child home injuries. A survey of parents ofpreschool children. 3, (1): $29-34$.

Jalal F, Soekirman, 1990. Pemamfaatan antropometri sebagai indikator sosial ekonomi. Gizi Indonesia. Badan perencanaan pembangunan nasional. No.14 (2). Jakarta, hlm 27-35.

Ivanovic R, Olivares M, Ivanovic D, 1990. Nutritional status of urban and rural children school children of the metropolitan area. Pediatr, 61 (4): 210-217.

Ivanovic D, Olivares M, Castro C, Ivanovic R,1995. Nutritional status of school children in proverty condition from urban and rural area. Metropolitan region Chile. Rev Med Chil. 123 (4): 509-525.

Panter-Brick C, Todd A, Baker R, 1996. Growth status of homeless Nepali boys: do they differ from rural and urban controls. Soc, 43 (4): 441-445.

Rona RJ, Chinn S, 1995. Genetic and Enviromenttal Influences on Growth. J.Med Screen, 2 (3): 133 - 139 
Rousham EK, 1996. Sosio-economi influences on gender inequalities in child health in rural Bangladesh. J Clin Nutr, 50 (8): 560 - 564 .

Sanchez-Andris A, 1998. Genetic and environmental influances on somatotype familiy study in Spanish population, Human Biol, 67 (5): 727-738.

Shen T, Habicht JP, Chang Y. 1996. Effect of economic reforms on child growth in urban and rural areas of china. J Med. 335 (6): 400 - 406.

Tanner JM, 1978. The curve of growth. Foetus into man : Physical growth from conception to maturity. Open books publishing ltd. London, pp 6-36, 117-153.

MEDIKORA Vol. IV, No 2, Oktober 2008: 109-129 